\title{
Democracy and the New Dimensions of Civil Agitation in Post 1990 Nigeria
}

\author{
Luke Amadi ${ }^{1}$, George Anokwuru ${ }^{1}$ \\ ${ }^{1}$ Department of Political \& Administrative Studies, university f Port Harcourt, Nigeria
}

\begin{abstract}
This article explores democracy and resurgence of civil agitation in Nigeria. It examines contemporary dimensions the civil agitation had taken and how such agitations either contribute or derail democratization process in Nigeria in the context of violent terrorist attacks, sectarian killings, clamor, for self determination, civil unrest, militancy and destruction of material resources. It argues that understanding the fundamental intricacies and nexus of the ongoing agitation in a plural society is critical for policy and research agenda which seeks to explore the tenacity of democracy deepening. To advance a cohesive argument, institutional framework was adopted and extensive data which derive from fieldwork in Nigeria, which at the same time helps illuminate recent broader issues and on the ground evidence associated with civil agitation and its effects on Nigeria's democracy.
\end{abstract}

Keywords: Civil Agitation, Democracy, Civil Society, Politics, Development, Nigeria

\section{INTRODUCTION}

The return to democracy in Nigeria in 1999 suggests the reinvigoration of political engagements from various social groups of varying ideology and inclination within the political space provided by democracy. Huntington's Third Wave democracy (Huntington, 1991) points out a new political space resulting in some sort of quest for popular and collective participation in governance, a glaring departure from the authoritarian one party system that characterized African politics.

Following democratization, resurgent civil agitation became palpable and often inevitable. The long marginalization of the oil rich Niger Delta region inspired by poverty, re-opened to view an entirely new mode of agitation namely militancy and youth restiveness. Before the resurgence of militancy, the agitations of the Ijaw Youth Congress (IYC) which is an association of the Ijaw ethnic nationality, an oil rich minority ethnic group in Nigeria has been discernible. Their mode of operation remains largely non -violent. For instance, in 1998 it spearheaded the Kaiama Declaration though its aftermath was a tumultuous crisis.

Equally, another minority ethnic group namely Ogoni, under the platform- Movement for the Survival of Ogoni People (MOSOP) has been a non-violent group swirling with varying degrees of ethnic agitation against human and environmental rights violation. MOSOP was established in 1990, it began campaign for greater control over oil and gas resources. It's demands were summarized in their 1990 'Ogoni Bill of Rights'(OBR).The particular case of MOSOP is important as the group through the resilience of its late founder Ken Saro Wiwa who was executed by the Nigerian federal military government in 1995, internationalized the Niger Delta minority agitation.

In the Middle Belt region, there is a long history of minority struggle like the oil rich Niger Delta. The Middle Belt is predominantly non-Muslims. Barnes (2007) has provided useful insights in understanding the historic antecedents to the region's struggle particularly against being subservient to the emirate system of the north as Christians. The Middle Belt Forum (MBF), has been a strong rallying point for the people under which they galvanize their collective struggle.

Following nascent democracy, the Niger Delta militant youths took to the creeks as a result of poverty and marginalization. This resulted in the taking into hostage of expatriate oil workers and vandalization of oil pipelines by the agitated youths. Other incidents followed almost simultaneously with complex outcome notably the rise in self-determination agenda propagated by the Indigenous Peoples of Biafra (IPOB) in South East Nigeria-, a region that belonged to the defunct Biafra that 
fought a thirty month civil war (1967-1970) when they seceded from the republic of Nigeria in 1967, predominatly of the Igbo ethnic extraction (one of the three major ethnic groups in Nigeria).

This scenario which suggests a flurry of social disorder also culminated into related contradictory and senseless violence such as the Fulani herdsmen and killing of farmers in several parts of rural Nigeria which gained popular and disturbing currency since the President Buhari administration on May 29th 2015.Worse, is the plague of the herders attacks in the Middle Belt region and parts of South Eastern Nigeria. There is also the massive killings of the Boko Haram terrorist sect in North East Nigeria which deploys several tactics such as abduction, detonation of bombs by suicide bombers, direct attacks and killing of innocent citizens and several cases of internally displaced persons (IDPs). Others include the Shiite Sect in parts of northern Nigeria and the Badoo cult group in parts of South Western Nigeria. The latter is engaged in ritual killings and kidnapping while the former is known for sectarian violence. Nigeria has taken a form of a society with institutional decay, insecurity, and seemingly criminal anarchy which pose real and latent threat to human security and everyday life.

In almost two decades of Nigeria's democracy, civil agitation has taken several coloration threatening the unity and corporate existence of the country. Thus, issues of egalitarianism, equality, cultural and ethnic tolerance, true federalism, effective macro-economic policy which are key ideals of democracy, remain less clear in real governance contexts. Whereas democracy has been fully accepted in Nigeria, it has not delivered the much expected transparent and equitable governance. Several sectors of the federating units are either in pursuit of one sectional interest or the other, most of which perhaps may run counter to the alleged "unity" of Nigeria. Getting the trends proper in collective and inclusive governance contexts remains at issue. This has been part of the wider problem of Nigeria contextualized within the "national question" debate which has rarely been adequately resolved.

Undeniably, the intensity of these governance challenges are an attribute of the colonial legacy and its flaws which include the lumping together of peoples of different ethno-religious, political and cultural backgrounds. This not-withstanding, scholars of democracy argue that there is "no time to forsake democracy" in Africa (Barkan, \& Gordon ,1998 ). The evidence in Nigeria of persistent civil agitation particularly by the peoples of South East and South-South Nigeria provides a critical reappraisal of democracy and the new dimensions civil agitation had taken. This suggests the need for critical engagement with the question regarding the practicability of the ideals of democracy in Nigeria within the contemporary liberal order notably equality, freedom, accountability, transparency, ethno-religious tolerance etc.

Thus, the pursuit of a liberal state may not be insulated from social justice, accountability and equality in a country of disparate ethnic group like Nigeria. This results in the deepening contradictions of State legitimacy crisis and tenuous State/ civil society relations. This agitation was perhaps worsened by the inability of the State to improve the economic situation of the country which has been in a recession since the late 2016 and 2017.

Against this background and to capture the policy relevance of these persistent trends, the paper will attempt to introduce new conceptual material from fieldwork and engage systematically and thoroughly with the existing literature in order to make a fresh contribution to the debate. In particular, identify and analyze these resurgent trends to provide post 1990 changes in civil agitation in Nigeria. It is necessary to examine the new dimensions the agitation had taken and how they pose threats to democracy deepening and transformation in Nigeria. Beyond this, the article aims to clarify some of these salient issues which are both developmental, policy relevant and implicit in the existential realities of Nigerians at the post 1990 democracy.

Drawing insights from the institutional approach, the paper explores these interrelated issues and how they trigger civil agitation. It examines two typologies of civil agitation and discusses same with relevant on the ground evidence. Essentially, it captures why and how policy framings should be directed to meet the needs of the disparate groups in Nigeria . The first section of the article lays out the theoretical framework to guide the analysis of the study, the second describes the conceptual analysis, the third discusses dimensions of the new civil agitation followed by a conclusion.

\section{THEORETICAL FRAMEWORK}

Institutional theory examines interactions and actions among societies and organizations. Issues of democracy transition spans across the developing democracies of the Third World such debates inform and underpin the importance of institutional structures in driving the democratization process. 
Studies on institutions either from political, religious or cultural frameworks have attracted a number of stimulating attention to examine both micro and macro institutional strands (Scott, 2004).

Thus, there are a number of insightful institutional theoretical perspectives. For instance, the institutional failure debate within democracy contexts, points out the inability of the State to institutionalize democracy culture. Linz and Stephan (1996, p.1) contend that "no State, no Democracy'. This informs the interface of State and democracy. Aidt (2010) addresses the importance of political institutions in driving the developmental process indicating why institutional structures are key to development. This has been elaborated with the increasing emphasis on the linkages between institutional forces and organizational systems. Scott (2004) established how institutional forces shape organizational systems.

Africa has often been described as a region with less formal institutional rules (Batch, 2004; Posner \& Young, 2007). For instance, Posner and Young (2007:127) argue that despite the existence of a number of formal rules which include the constitution, that these rules play less significant roles in checking leaders" behavior. This in their views is reflected in the "personal rule" or "Big Man" paradigm which has been a defining variable in understanding African politics for the past thirty years (Posner \& Young, 2007: 127). This is supportive of debates that blame the failure of democracy on the absence of State, such debates are consistent with democracy failure in Africa (Batch, 2004; Amadi, et al; 2016). The State failure in Africa is reinforced with the "politicization of governance debate" (Amadi, et al; 2016), in which core tenets of governance and formal institutional rules are reduced to "politics" including ethnic and patrimonial ties.

Institutional variation debate contends that institutions are endogenous due to variations on a number of issues including formal versus informal institutions. Other factors include geography, ecology, climate, culture and related factors affecting exogenous component of productivity or technology (Acemoglu,et al;2001).

Similarly, Stephan and Dercon (2009) made cogent remarks on the contradictions of capitalist institutional failures in the third world. They contend that trends since the mid-nineteenth century suggest that capitalist institutional system has 'erected positive barriers to economic development'. The global institutional failure framework re-echoes the persistent asymmetry in the international capitalist system which suggests global inequality and underdevelopment of the poor societies (ImohItah \&Amadi, 2016).

The empirical evidence of the primacy of economic institutions in explaining comparative economic development is overwhelming (Acemoglu, et al; 2001).To make the theoretical framework operational for democracy policy investigation, it has to be understood that civil agitations, popular uprisings, militancy, demonstrations, civil riots, alleged marginalization etc cannot be regarded as separate issues in a democracy .Closer collaboration is needed, institutional approach provides such seminal framework for integrating democratic institutions to action sets linked to civil agitation. Particularly, there is argument for institutional policy overhaul and changes in policy-making process ( Levine, 2014) which could contain the needs of the disparate groups in Nigeria and address the persistent civil agitations. Batch (2004, p.1)argues that Nigeria, is confronted with challenges, of institutional capacity, resulting in the " erosion of citizenship and the promotion of parochial values".

\section{Democracy And Civil Agitation: Some Conceptual IsSues}

Democracy in the developing societies seems to have demonstrated limited commitment to democracy culture (Huntington, 1991; Held, 1993; Ake, 1993; Kapstein \& Converse, 2008; Leon, 2010). Despite the persuasions of liberal proponents (Barkan, \& Gordon, 1998), there are abundant literature discussing aspects and implications of poor democracy culture as growing patrimonial attachments and ethnic politics are such consequences (Nnoli,1978;Ake,1993). Although attempts to allay ethnic minority fears in Nigeria was first addressed with the setting up of the Willinks minority commission in 1958 (Ekekwe,1986), evidence of ethnic minority fears and separatist agitation remains pervasive(Tamuno,1970).

Post independent Africa has often been described as riddled with political and ethno-religious crisis (Legum, Zartman, Langdon \& Mytelka, 1979). The divergent colorations of post 1990 civil agitation have often been subsumed under ethno-religious strands as there are often methodological difficulties in clarifying civil agitation dynamics in plural societies like Nigeria .Much of the reoccurring conflicts 
and agitations have been linked to "Old Hatreds" (Egwu, 2006). Nnoli (1978:8) contends that ethnicity is a very complex phenomenon. "Its complexity is not always adequately reflected in sociopolitical thought. He argues that the prevalence of ethnicity in Nigeria is indisputable and that it plays significant roles in the society suggesting the emergence of new variables within its content. Burton (1979) provides seminal debate on aspects of agitation which links deviance and terrorism with war. He re-inscribes the political problems it poses to governance. In contemporary times, civil agitation poses similar threats that special importance ought to be attached to the elucidation of the relationship between democracy and civil agitation. A key factor in understanding such simmering interface is the character of State in Nigeria.

Ake (1985) summarized this scenario in analyzing State in contemporary Africa, as a specific modality of class domination, arising from commodity exchange. This creates a domineering institutional mechanism.

The diverse ethno-religious structure of Nigeria provides a key defining context for a number of political factors including the power of numbers and inter-ethnic domination in its electoral democracy (Ibrahim \& Egwu, 2008). The vast ethnic and social structures in Nigeria have different attachments and sentiments to socio-political issues which the elite appropriate to achieve their interests within various political scenarios (Ibrahim \& Egwu, 2008).

Such variations in population, geographic spread, history, culture and language, illuminate the drive to understand the contest, struggle and context of civil agitation in Nigeria. Implicit dissonance often emanates from the quest to maximize and exploit material resources for sectional rather than national interest. This accounts for "micro nationalism" and obvious failures in major "national endeavors" such as evolving exact census figures, conducting credible elections, national commitment by public office holders, issues of fiscal federalism, balanced governance structure etc.

Civil agitation emerges as a result of proliferation of several 'new movements', that mobilize actions against the State as they claim to be marginalized, oppressed or exploited in the capitalist order. They propagate new ideologies, that represent their belief. A number of socio-cultural and political factors are important in the understanding of civil agitation. Ethnic factor is one of the institutional frameworks of civil agitation mindset and behavior as explicated.

Otite,(1990) argues that Nigeria is a plural society made up of about 374 ethnic groups.Some studies have demonstrated linkages between ethnicity and macroeconomic outcomes suggesting poor policy choices (La Porta, et al. 1999;Laven,2014) . Hofstede (1994) reinforces such implications emanating from 'strong tendency for ethnic or linguistic recognition' as basis for identity. Where such identity is suppressed or marginalized it could trigger agitation. Thus, civil agitation has often been associated with ethnic politics and identity on one hand (Rotchild, 1963; Nnoli, 1978; Diamond, 1987; Akande,1988;Ekeh,1990;Gurr,1993;Suberu,1996,Egwu,2001;Obi,2001), and the quest for a fair share of the "national cake" on the other.

Ekeh (1990) contends that the power of ethnicity in Africa has deep roots in pre-colonial history and social psychology. He demonstrates that the weakness emanating from the inability of the colonial state to protect the people from slavery resulted in strong kinship ties as 'state surrogate'. Such ties according to Lijphart (1984) are ' along religious, ideological, linguistic, cultural or, ethnic lines '. This is constitutive of separate sub-societies each with different interests and modalities for pursuing such interests.

Such sub societies exist within distinct but coordinated political economy. In Nigeria civil agitation operates within similar dimensions such as ethno-religious, economic, political and socio-cultural. Such structural specifications suggest how civil agitation is acted out and propagated as instrument of both political and economic relevance. Thus, displaying the acute sensitivity towards the interdependence of State actors on ethnic affinity and identity. This understanding informed the post civil war ethnic balancing such as the 1979 federal Character Principle adopted in Nigeria's second republic, the zoning formula introduced at the return to democracy in the late 1990s among the six geopolitical zones well recognized as the basis for sharing power and promoting equity in the federation although not constitutionally entrenched.

There are economic factors which account for the patterns of agitation within the interaction of the forces of production, distribution and exchange in a given social formation. For instance, in a 
multiethnic State like Nigeria, the oil resource bearing communities often agitate on the basis of poor fiscal federalism and marginalization by the Nigerian State. Thus, the need to evolve equitable revenue sharing formula remains at issue in an unequal multi -ethnic society like Nigeria.

Despite the attempted balancing, true federalism remains at issue including equitable fiscal federalism and post-civil war marginalization of the Igbo (Mustapha, 2004). These contradictory images in the federal system of Nigeria often provide defining contexts of resurgence of civil agitation. For instance, in the 2000s the youths of the marginalized oil minority areas of the Niger Delta took to the creeks to legitimize their grouse against the Nigerian state with oil pipeline vandalization and abduction of expatriate oil workers. Equally, the re-emergence of pervasive agitation by the IPOB creates novel awareness on palpable worries in five decades of the Nigeria/Biafra civil war.

The extent to which these agitations and similar informal rules are giving way for formal rules in Nigeria's democracy has been of novel scholarly importance in understanding the quality of Africa's democracy(Bratton \& van De Wall,1997). In a related account, Horowitz (1994) pointed out that although democratization is a worldwide phenomenon, it is neither universal nor uniform in places where it exists. A significant element of institutionalizing democracy centers on "consolidation of democracy", Linz \& Stephan (1996:1) have shown that "democracy consolidation is largely unconnected with non- democratic institutions where non "liberalized regimes", or "pseudodemocracies", or "hybrid democracies" exist. They argue that "only democracies can become consolidated democracies".

Thus, governance needs to go beyond legitimization of institutions rather institutionalization of democracy values and ethos which translates to democracy culture. Conversely, where governments' incentives are at odds with democracy culture with propagation of personal rule, institutional corruption, electoral fraud, favoritism, ethnic parochialism and sentiments, the tendency for democracy transformation becomes a challenge. The controversy surrounding this phenomenon is reflective of the intense civil agitation and debate on the developmental and policy relevance of a democratic government. This lingering debate in a plural society like Nigeria has resulted in increasing doubts on emancipatory claims of the Nigerian state which fosters the rise in ethnic tension and agitations as Ake (1993) recounts the dominant notion in which most Nigerians conceive the State as 'an alien, hostile and coercive power' resulting in a 'transfer of loyalty' from the State to , ethnic nationality.

Recent debates on dynamics of Third World politics especially Africa are supportive of evidence of this later strand (Diamond, 1987; Bratton \& van de wall, 1997; Egwu, 2001; Amadi \& Ekekwe, 2014). Such hypothetical analysis has been important in closer observation of recent trends and changes in a democratic government. Recent events in African politics point to the fact that the rule of the game is increasingly changing despite how minimal the results might have been, at the moment the 'big man' government, the 'personal rule', 'patrimonial autocracy', 'one party system' is slowly but persistently giving way.

Posner and Young (2007) pointed out the particular case of President Obasanjo of Nigeria whose bid for a third term after eight years in office (1999-2007) was scuttled. They argued that this points out that 'the formal rules of the game which were ignored are beginning to matter in sub Saharan Africa. Similarly, the recently concluded 2015 general elections in Nigeria reflected a deep seated relevance in the annals of Nigeria's and indeed Africa's democracy as an incumbent President Jonathan conceded defeat at the polls to an opponent from the opposition All Progressives Congress (APC).

These impressive records not-withstanding, there are increasing evidence of draw backs which puts developing Democracies in a downward spiral such as the massive killings in the North East Nigeria by the Boko Haram terrorist groups, and millions of internally displaced persons (IDPs), popular agitations such as the Niger Delta militancy and the recent uprising by the Indigenous Peoples of Biafra(IPOB),the persistent killings and attacks by the Shiite sect, the herders attacks on rural farmers etc.

These agitations and crisis which may likely pose latent challenges to democracy consolidation and deepening in Nigeria are important policy discourses as discernible democracy scholars as Larry Diamond re-echoes "democracy recession" in a 2015 article which argues that novel democracy strides have been less clear (Diamond,2015). 
In the face of growing literature, few attempts have been made to examine and conceptualize the emergent dynamics of post 1990 civil agitation. Studies theorizing civil agitation in a nascent democracy have been scant. This points to the saliency of new look at democracy and civil agitation in Nigeria. This study advances a new theoretical model which posits that civil agitations might be either civil or violent and increasingly constitute a set of social groups which strive to attract State attention. In what follows, the article examines the new dimensions of civil agitation in Nigeria to deepen the debate on Democracy in Nigeria. This is linked to cohesive on the ground evidence on the broader elucidation of civil agitation and democracy nexus in Nigeria. A brief exploration of these ongoing trends is important to examine the casual connections and in particular, explore how these trends are shaping democracy in Nigeria. Policy attention and further research is required as the concept of civil agitation in a developing democracy is not only interesting but useful tool for exploring democracy in a plural society as a number of recent changes are taking place.

\section{New Dimensions of Civil Agitation at the Post 1990 Nigeria}

Civil agitations are not so new in Nigeria, what is new is the dimensions they had taken since the return to democracy. Between the post 1990s and 2000s, there have been studies pointing out the rise in civil society groups in Nigeria (Ikelegbe, 2001). Glowing debates that democracy will douse civil agitation have been contradictory.

There have been a number of challenges in Nigeria's federal system often linked to the persistent civil agitation notably the federal character principle, minority rights and revenue allocation formula in which priority was accorded to demography rather than derivative principle that remained basis for revenue allocation before 1970 when cocoa and groundnut were major export produce of Nigeria. Civil agitation including violent crisis remains visible. These trends and changes which are not often studied in sociology of development of Nigeria point to the saliency of investigating ongoing events in Nigerian politics.

A number of scholarly debates had examined aspects of civil agitation in Nigeria. Historian Tekena Tamuno (1970) had provided a genealogical mapping of separatist agitation in Nigeria since 1914 when the Northern and Southern protectorates were amalgamated. The central argument has been the challenge of colonial amalgamation of religious and ideologically different groups into one country. Much of the subsequent agitations which largely took ethnic coloration have been examined and linked to colonial legacy .For instance, Nnoli (1978) shows that ethnic politics is a colonial legacy and this perhaps reinforces its pervasive rise evident in the patterns of civil society agitation in postcolonial Nigeria.

Such manifestations demonstrate the increasing need for a new look at civil agitation in Nigeria as it appears in public sphere with divergent colorations which seems to blur fuller comprehension between the 1990s and the 2000s .Such agitations often serve as a mode of social consciousness, political legitimacy and relevance, in particular a nucleus of the civil society.

\section{Towards a Typology of Civil Agitation in Nigeria}

Since the 2000s, palpable multi-ferrous crisis, strife, religious bigotry, ethnic minority agitation, postcivil war marginalization and agitation of the Igbo, remained an endemic source of social disorder in every nook and cranny of the country. The reoccurring vortex of civil agitation and conflicts with long political history continues to swirl and prove to be a problem in Nigeria in real and latent sociopolitical and economic contexts skulking in the background as an inevitable threat to democratization.

Some are sectarian and ethno-religious resulting in carnage and insurgency, others are violent disruption of capitalist resource expropriation as in the Niger Delta militancy, others are informed by post-civil war marginalization as replicated in the IPOB. We conceptualize two key dimensions namely violent and non -violent. This could be examined in the subsequent section.

\subsection{Violent Dimensions}

A new generation of post 1990 violent agitation is discernible. The early 1990s saw the post June 12 Presidential election annulment agitation and riots spearheaded by the Odua Peoples Congress (OPC) under the leadership of Ganiyu Adams. The agitation was largely violent as several citizens flee from Lagos to their home States while several others died. 
In the 2000s, a similar agitation was exemplified in the resurgence of Sharia law protests in parts of northern Nigeria notably by non-Muslims in Kaduna north Western Nigeria. This, extended to other parts of northern Nigeria in the late 2000. The core issue was the Islamization of northern Nigeria and particularly the propagation of Islamic penal codes in the northern states of Nigeria. The sharia penal code and its terms were contested by Christians in northern Nigeria resulting in violent agitations and several loss of lives under the Obasanjo administration. Guided by the glaring dogmas of Muslim religion and teachings, this was largely embodied by a more strict implementation of the Sharia law. It was built and followed closely by fierce and pervasive ethno- religious identity and affinity as simple paradigm for reinvigorated relevance in the north.

Equally, new religious fundamentalist leaders undeterred by alleged nascent democracy begun the strive for Islamization of northern Nigeria and to capture parts of North East Nigeria as their territory in the name -Boko Haram, denoting that "Western Education is evil". The sect is a terrorist group which emerged in the North East Nigeria in the 2000s. Perhaps since Nigeria's return to democracy in 1999 there has never been such recorded massive killings.

The cataclysm of the Boko Haram sect pressing for occupation of parts of northern Nigeria as its territory has resulted in repeated terrorist attacks and counter insurgency by the Nigeria military. Imoh-Itah, Amadi and Akpan(2016) recount that since 2004, the North East had been besieged with persistent violent attacks resulting in humanitarian crisis. This includes bombings, burning down of houses, use of fireworks, explosives and abduction. They corroborated the International Organization for Migration's reports that in six years, Boko Haram had displaced more than 2.1 million -- or 300,000 households in North East Nigeria (Global Terrorism Index,2016;Imoh-Itah ,et al;2016). The insurgent group hoists their flags in some captured regions in the North East and chant several songs in Islamic language.

The UN, General Resolution, (1994) which criminalized terrorism argued that the term terrorism in modern security studies is both criminal and derogatory and denotes a situation of absence of morality and legality. There have been serial terrorist attacks, suicide bombings, abduction and killings in Maiduguri and parts of North Eastern Nigeria since 2004. Others include the bombing of Mogadishu Military Cantonment Mammy Market in Abuja the capital of Nigeria on December $31^{\text {st }}, 2010$ (Omole,2013). A particular defining feature of their mode of operation has been the abduction of youths and compulsive conversion of teens into Muslim including the girl child. The serial bombings and attacks have resulted in internally displaced persons (IDPs), including the burning of houses, out migration and deaths of thousands of innocent citizens.

Similar accounts were to follow notably, in Bauchi, and Zuba near Abuja in 2011 there were the bombing of mammy markets (Omole, 2013). Another attack by the group was the post-April ,2011 Presidential election violence in parts of northern Nigeria. On April 8, 2011, there was bombing of the Independent National Electoral Commission (INEC) Office in Suleja near Abuja. A related incident occurred on May 29, 2011 in which a social drinking sport in Maiduguri was attacked another occurred almost simultaneously in Zuba area outskirts of Abuja (Omole, 2013; Imohita, et al;2016).

Others followed which included the bombing of the Nigeria Police Force Headquarters in Abuja on June 16, 2011, the bombing of UN House in Abuja on August 26, 2011, the bombing of Army Task Force, Operational Police Headquarters on Nov 4, 2011. The attacks and bombing on $25^{\text {th }}$ December (Christmas Day) of St Theresa Catholic Church in Madalla near Abuja. Again between $5^{\text {th }}$ and $6^{\text {th }}$ January,2012, there were attacks and bombings in places like Yola, Mubi Gombe and Maiduguri all in northern Nigeria .On January $20^{\text {th }}$ and February $1^{\text {st }}$ 2012, there were bombings and killings in Kano. Equally there was the bombing of Kawo bridge in Kaduna and the head quarter 1(HQ 1) Division Nigerian Army on the $7^{\text {th }}$ of February, 2012) (Omole,2013).

Most remarkable was on the night of 14th April 2014, where two hundred and seventy six female students were kidnapped from the Government Secondary School in the town of Chibok in Borno State, whose whereabouts remains a mirage. There was the Nyanya and Mararaba suicide bombings of October, 2015in Abuja among several .The sect and their activities seem to defy counter insurgency strategies of the Nigerian military.

In recent times, there is no exact data on human lives lost to Boko Haram terrorism including men, women and children. Perhaps beyond loss of lives and property, many still fail to comprehend the extent of the threats posed the brutal Muslim fundamentalist group. The Global Terrorism Index 
recorded almost 18,000 deaths in the year 2013, a jump of about $60 \%$ over the previous year. It reported that most of the deaths were linked to Islamic State (ISIS) in Iraq and Syria, the Taliban in Afghanistan, Boko Haram in Nigeria and al-Qaeda in several countries of the world (Global Terrorism Index,2016). The Boko Haram attacks have been as dangerous as the ones in Afghanistan, Iraq, Syria, Pakistan etc.

Despite the killings and displacement of several people, on the 7th of March, 2013, the Sultan of Sokoto, Alhaji Sa'ad Abubakar, called for "total and unconditional" amnesty for the Boko Haram sect. Nwankpa(2014 ) had provided a comparative analysis of Boko Haram terrorism and Niger Delta militancy to debunk the clamor for justification of amnesty for the Boko Haram terrorist group like the Niger Delta militants.

There are conceptual debates on key ethno-religious ideology and identity that drives Islamic terrorism. Allen (2009) deployed the concept "Wahabism" which denotes a Muslim ideology that propagates religious belief on identity grounds. Allen (2009) argues that this has been a common characteristic of the Muslim fundamentalist groups primarily informed by the penchant to protect their ethno-religious identities.

Another wave of violence of ethnic coloration is discernible with the rise of the Shiite sect which washed across parts of North West Nigeria and provides some catastrophic challenges to peace and security in the North Western Nigerian states. Initially triggered by a wave of ethnic agitation in Kaduna former capital of the defunct Northern Nigeria in the early 2000s, and the disruptive crisis that persistent arising from attacks by the sect. The Shiite sect recently unleashed terror in the neighborhood with killings totaling about 200 in Kaduana compounded with the recent assassination attack on Nigeria's Chief of Army Staff, General Buratai. In Kaduna in 2016, the sect unleashed several violent attacks including the convoy of the Chief of Army Staff, while he was on his way to pay homage on the Emir of Zazzau and the Passing Out Parade of 73 Regular Recruits Intake of Depot Nigerian Army in Zaria. (Premium Times, 2016). The sect had also made parts of the region ungovernable with most recent attacks and killings.

The surge in ethno-religious pastoral carnage of the Hausa/Fulani herdsmen in the adjoining nonMuslim states of the north extending to Benue axis in the North Central and Kaduna in the North West and Oyo in South-Western Nigeria to Enugu in the South-East and parts of South-South Nigeria provide similar disruptive image of the ongoing civil agitation.

Perhaps the most incendiary was in Agatu a small community in North Central Nigeria which took place simultaneously with the Shiite crisis in the North West causing a maelstrom of disaster and killings in several adjoining northern Nigerian communities. In the month of March 2016, the Agatu region of Benue State had one of the most recent provocative attacks as Fulani herdsmen armed with AK-47 rifles attacked some villages and farm settlements in broad daylight, They killed men, women and children(Mayah,2016). About 300 villagers were reportedly massacred in communities like Agila, Okokolo, Akwu, Adagbo, Odugbehon and Odejo. Extending from Agila to Obagaji, Akwu to Odejo, houses, churches and police posts were burned down. Human corpses were littered everywhere (Mayah, 2016).This included men and women while several others were displaced.

In Kaduna more than 200 people were killed following attacks by suspected Fulani herdsmen in some villages in the State, about 50 persons died. Another terror was unleashed on two other villages on Saturday 9th April, 2016 in which over 150 people were killed.

The Niger Delta militant agitation typifies another violent civil agitation in the South -South Nigeria. Although the agitation started as a non-violent struggle largely motivated by the demands for equitable resource control. The marginalization of the ethnic minority area has been at issue. This results in ethnic strife .Cohen (1969) argues that ethnicity underscores strife between groups informed by the inevitable emphasis on peoples' identity and exclusiveness. The ethnic minority question for instance has been at issue since the 1958 Willink's Commission and has not been adequately addressed. Amadi, Imoh-Itah and Obomanu (2016)had provided a seminal classification of the Niger Delta struggle from the 12 days revolution of Adaka Boro in the 1960s to the environmental activism of Ken Saro Wiwa of the 1990s and used the term 'militia capitalism' to explain the patterns of post 1990 militancy in the Niger Delta. The transition Niger Delta agitation had witnessed from "voice to 
armed struggle" points out the fierce turn militancy had taken in recent times as a result of resource marginalization and environmental degradation. Thus, the rise in militia groups and quest to control the oil economy fueled violent agitation.

There emerged a number of fierce ethnic militia groups notably the defunct Niger Delta Peoples Volunteer Force (NDPVF), headed by Alhaji Asari Dokubo, Movement for the Emancipation of the Niger Delta People (MEND)led by Emma Okah and its wing in Delta State known as Camp five headed by Chief Government Ekpemopolo (a.k.a) Tompolo, Niger Delta Vigilantes (NDV) led by Chief Ateke Tom,The Outlaws led by Sogboma George among several others. Their mode of operation included vandalization of oil facilities and abduction of expatriate oil workers.

In 2009 the federal government granted amnesty to the militant youths. At post amnesty, fierce militant groups re-emerged notably the Niger Delta Avengers which has caused endemic violence on oil pipelines in the region. This has resulted in killings and militarization of the Niger Delta region.

The ongoing evidence and similar others could be linked to the causal connections between Nigeria's democracy and the challenges of civil agitation transformation and emancipation. In almost two decades of Nigeria's democracy, civil agitation has not only taken novel colorations and disrupted democracy deepening rather has provided increasing threats and evidence of, government's failure to "democratically" resolve most of the growing challenges .For instance, the Niger Delta resource problems remains largely unaddressed as youth restiveness and agitation have not ebbed. Key issues of resource allocation and revenue formula have not been adequately addressed, the UNEP recommendations in 2011 for effective clean-up of the environmentally polluted Ogoni an environmentally degraded community in the Niger Delta has not fully seen light of the day.

\subsection{Non Violent Dimensions}

There have been re-invigorated civil agitation in South Eastern Nigeria as the group that belonged to the defunct Biafra has been clamoring and agitating for a separatist agenda as they allege to have not been effectively re-integrated into the Nigerian State since the end of the thirty months civil war (1967-1970).This is predominantly in the context of holding key political offices including the President of the federation since the end of the civil war.

In the 1990s, the emergence of the Movement for the Actualization of a Sovereign State of Biafra (MASSOB) in the South East, rekindled the secessionist agenda of the defunct Biafra with its leader Ralph Uwazuruike. The group which hoist Biafra flags in the region belonging to the defunct Biafra were largely non- violent and organized several peaceful demonstrations.

In the 2000s, the Indigenous Peoples of Biafra (IPOB) a civil society group from the defunct Biafra Republic clamoring for self -determination emerged. Popular civil uprising ensued in Eastern Nigeria with the quest for a separate republic. In several instances of mass protest, members of the IPOB were attacked, shot and detained by members of the Nigerian police force. Such crackdown had intensified the agitation as there was no avenue for a national dialogue on the issues raised by the group. Former President Obasanjo had described them as those who are "seeking for attention" (Obasanjo, 2016). The leader of the group Nnamdi Kanu who is also the Director of the Radio Biafra spearheaded the agitation.

On October 2015, the federal government of Nigeria arrested Kanu. Prior to the IPOB uprising, the region has been agitating for effective post-civil war reintegration and infrastructural development. In April 2017, Kanu was granted a conditional bail (Opejobi, 2017). On June $30^{\text {th }} 2017$ which marked 50years anniversary of the declaration of the defunct Biafra Republic, IPOB leadership charged every citizen of the defunct region to have a sit at home solidarity demonstration which was effective in the five eastern States and parts of Igbo speaking communities in Delta State South-South Nigeria. Economic activities were stalled. As a consequence, the youth wing of the Arewa Consultative forum (A Pan Hausa/Fulani association) gave all Igbos residing in the north ultimatum to vacate the north from June 10 to October $1^{\text {st }} 2017$, charging them that all their properties in the region should be forfeited as they depart. This created tension in the polity

In the month of September, 2017 the federal government launched Operation Python Dance II in the entire Eastern Nigeria. During the exercise several innocent citizens were killed in the cities of Aba and Umuahia. In particular, Kanu's home was raided by the military. Subsequently IPOB was 
proscribed by the Governors of Eastern Nigeria and later the federal government who tagged the group a terrorist group. Whether the proscription of the group is democratic or could bring the agitation to an end remains a subject of future research.

\section{CONClusion}

The agitations discussed and several others which have both ethnic, political and religious colorations point to the novel turn civil agitation had taken since nascent democracy in the 1990s. Where- as the colonial and immediate post-colonial agitations were largely non-violent, the post 1990 agitation has been both violent and non-violent resulting in killings and distinctively opening the pattern of Nigeria's democracy to further interrogation and research agenda. Thus, the key issues triggering civil agitation in Nigeria seem not to have been adequately addressed and will remain topical in the political economy of Nigeria. All these offer fresh arguments on theoretically informed ethnographies of social and political relations in an era of nascent democracy in Nigeria and in particular, provide on the ground understanding of contemporary and most incendiary trends in democracy and civil agitation in Nigeria, which are sensitive to local, cultural, political and global economic realities and needs policy attention in a multi -ethnic society like Nigeria.

Essentially, issues of democracy and civil society agitation in a plural society divided along ethnoreligious and cultural lines is ever important and remains central since the 1990s. These agitations have served as the dominant modes of attracting attention from the alleged marginalized groups in the federating units of Nigeria. Indeed, the sheer magnitude of the contemporary challenge to democratization in Nigeria are largely attributable to the fractured federal system and colonial legacies. Thus, the dynamics of civil agitation have not ebbed rather had taken more formal and often terrific dimensions as in the case of Boko Haram ethno religious sect, the Niger Delta ethnic militia agitations, the IPOB etc. This negatively impacts democracy deepening.

Effective accommodation of cultural diversity remains central to the processes and practices of a liberalized political order. Encompassing the long fears of the oil rich ethnic minority areas of the Niger Delta and post- civil war accommodation of the group that belonged to the defunct Biafra etc. These are rarely theorized in most scholarship on democracy deepening strategies and ethnic politics in Nigeria. The tendency for escalated ethnic or religious conflict is present in Nigeria, but it is not inexorable as ethnic intolerance, agitation, conflicts and perverse growth of civil unrest is imminent.

The increasing manifestations of civil agitation compels the critical need for urgent policy response as it appears that policy issues to address the grave problems posed by the agitations is largely ineffectual. This complex problem blurs fuller comprehension of Nigeria's democracy since the 1990s and in particular in the 2000s and remains important to the implicit understanding of the real apprehensions of the people.

\section{REFERENCES}

[1] Aidt, T. (2010). Corruption and Sustainable Development. In Rose-Ackerman S \& Søreide Teds., International Handbook on the Economics of Corruption, Volume 2, Cheltenham UK: Edward Elgar.CWPE 1061.

[2] Akande .J, (1988). The Minorities and the Challenge to Federalism, In Richard A.Olaniyan (ed.), Federalism in a Changing World. Lagos: Office of the Minister of Special Duties, The Presid ency.

[3] Ake, C. (1978).Revolutionary Pressures in Africa, London: Zed Press.

[4] Ake C, ed;.(1985).Political Economy of Nigeria,London:Longman.

[5] Ake, C. (1993). The Unique Case of African Democracy International Affairs 69, (2): 239-244.

[6] Allen, C.(2009). God's Terrorists: The Wahhabi Cult and the Hidden Roots of Modern Jihad. DaCapo Press.

[7] Amadi, L.(2012b).Democracy, Civil Society and Mass Action in Nigeria,A Case of Imo State Elections 2011.Parkistan Journal of Social Science 9 (1): 9-22

[8] Amadi, L \& Alapiki, H.(2014). Perspectives and Dynamics of the Natural Resource Curse in Post 1990 Niger Delta, Nigeria Journal of Advances in Political Science .1. (2).45-62

[9] Amadi L \& Ekekwe E, (2014).Corruption and development Administration in Africa: Institutional Approach .African Journal of Political Science and International Relations .8(6), 163 -174. 
[10] Amadi, L, Imoh-Itah,I, Obomanu F.(2016a).Oil: Niger Delta and The Making of Militia Capitalists:a theoretical assessment. International Journal of Social Science and Humanities Research 4, (1), 172-184.

[11] Amadi, L , Imoh-Itah I, Akpan R .(2016b).The State and Politicization of Governance in Post 1990 Africa: A Political Economy. International Journal of Political Science (IJPS) 2, (2).23-38.

[12] Acemoglu, D. (2005). Political Economy of Development and Underdevelopment Department of Economics Gaston Eyskens Lectures, Leuven. Lecture 1Massachusetts Institute of Techno logy.

[13] Acemoglu, D, et al;.(2001). The Colonial Origins Of Comparative Development: AnEmpirical Investigation, American Economic Review, 9(1). 1369-1401.

[14] Adam, C \& Dercon, S.(2009). The political economy of development: an assessment Oxford Review of Economic Policy, 25, (2),173-189.

[15] Anderson,B .(1991). Imagined Communities: Reflection On The Origin and Spread of Nationalism. (ed) Revised Edition. London and New York: Verso.

[16] Azar. E .(1990). The Management Of Protracted Social Conflict. Theory and Cases, Dartmouth, Aldershot.

[17] Bach, D. (2004).Nigeria: Towards A Country Without A State? Being the text of a paper presented at the conference on Nigeria: Maximizing Pro-Poor Growth: Regenerating the SocioEconomic Database, organized by Overseas Development Institute in Collaboration with Nigeria Economic Summit Group, London, 16-17 June.

[18] Barkan, J \& Gordon D. (1998). Democracy in Africa: No Time to Forsake It Foreign Affairs July/August.

[19] Barnes, A. (2007). The middle belt movement and the formation of Christian consciousness in colonial Northern Nigeria. Church History, 76(3), 591-610.

[20] Bratton .M \& van de Walle .N.( 1997). Democratic Experiments in Africa: Regime Transitions in Comparative Perspective New York: Cambridge University Press

[21] Burton, J. (1979). Deviance, Terrorism and War: The Process Of Solving Unsolved Social and Political Problems, New York: St. Martins Press.

[22] Burton, J (1997) Violence Experienced: The Source of Conflict Violence and Crime and Their Prevention". New York. Manchester University Press.

[23] Clapham, C. (1996).Africa and the International System: The Politics of State Survival, Cambridge; University Press.

[24] Cohen, A. (1969).Custom and Politics in Urban Africa: A Study of Hausa Migrants in Yoruba Towns. University of California Press

[25] Diamond L. (2015) .Facing up to Democracy Recession.. Journal of Democracy, 26, (1), 141 155.

[26] Diamond. L. (1987). Ethnicity and ethnic Conflict, The Journal of Modern African Studies 25 (1):117-128.

[27] Egwu, S . (2001).Ethnic and Religious Violence in Nigeria, Jos: St.Stephen Book Incorporated.

[28] Egwu,S .(2006).Beyond Revival of Old Hatreds: The State and Conflict in Africa In Shedrack,B (ed.) Introduction to Peace and Conflict in West Africa;Ibadan: A Spectrum Reader, Spectrum Books.

[29] Ekeh, P. (1990).Social Anthropology and Two Contrasting Uses of Tribalism in Africa', Comparative Studies in Society and History, 32, (4), 660-700.

[30] Ekekwe, E. (1986).Class and State in Nigeria London:Longman.

[31] Elaigwu, J. (1994).Ethnicity and The Federal Option in Africa. Nigerian Journal of Federalism.1, (1). 69-85.

[32] Glazer, N, \& Moynihan D. (eds;).(1975). Ethnicity and Experience. Cambridge. Mass. Harvard University Press. Atlanta Georgia.

[33] Gluckman,M .(1970).Tribalism in Modern British Central Africa,In I. Markovitz, African Politics and Society. New York: The Free Press. 
[34] Global Terrorism Index (2016) Institute of Economics and Peace. United States.

[35] Graf,W.(1979).Elections 1979.The Nigerian Citizen's Guide to Parties, politics, leaders and issues. Lagos: A Daily Times Publication.

[36] Gurr,T .(1993). Minorities at Risk; A global View of Ethno Political Conflicts, Washington DC, United States Institute of Peace Press.

[37] Held, D ed.,(1993).Prospects for Democracy: North, South, East, West. Stanford: Stanford University Press.

[38] Hofstede, G. (1994). Uncommon Sense About Organizations: Cases, Studies, and Field Observations. New York: McGraw-Hill.

[39] Horowitz, D. (1994), "Democratization in Divided Societies", in Diamond, Larry and Marc F. Plattner (eds), Nationalism, Ethnic conflict and Democratisation. Baltimore: Johns Hopkins University Press.

[40] Horowitz, D.(1985).Ethnic Groups in conflict. Berkely;University of California press Limited

[41] Huntington, S . (1991).The Third Wave: Democratization in the Late 20th Century University of Oklahoma Press

[42] Ibrahim. J \& Egwu. S. (2008). "Citizen action and the consolidation of democracy in Nigeria: A study of the 2007 Movement", available at www.drccitizenship.org/.../1052734610ibrahim _etal.2010-citizen

[43] Ikelegbe, A.(2001).The Perverse Manifestation of Civil Society: Evidence from Nigeria, Journal of Modern African Studies, 39(1):1-24.

[44] Imoh-Itah I \& Amadi L .(2016).Africa and Inequality in The International System at Post US Hegemony: A Modern World System Perspective International Journal of Political Science and Development, 4(1):31-43.

[45] Imoh-Itah, I, Amadi 1 \& Akpan R,(2016b). The State and Politicization of Governance in Post 1990 Africa A Political Economy International Journal of Political Science (IJPS) 2, ( 2): 2338

[46] Joseph, R. (1991). Democracy and Prebendal Politics the Rise and Fall of Nigeria's Second Republic, Ibadan: Spectrum Books Limited.

[47] Kapstein E \& Converse N.(2008), The Fate of Young Democracies Cambridge University Press.

[48] Kirk-Greene, A. (1975). The Genesis of the Nigerian Civil War and the Theory of Fear, Nordic African Institute, Uppsala

[49] La Porta, R. et al; (1999).The Quality of Government. Journal of Law, Economics, and Organization 15 (1): 222-79.

[50] Legum, C, Zartman W, Langdon S \& Mytelka, I.(1979).Africa in the1980s:A Continent in Crisis, New York: McGraw-Hill.

[51] Leon, T.(2012).The State of Liberal Democracy in Africa: Resurgence or Retreat?.The Cato Institute 1000 Massachusetts Avenue, N.W., Washington, D.C. 20001-5403www.cato.org

[52] Levan C. (2014).Dictators and Democracy in African Development: The Political Economy of Good Governance in Nigeria Cambridge: Cambridge University Press, Pp. 282.

[53] Lijphart, A. (1984). Democracies: Patterns of Majoritarian and Consensus Government in Twenty-one Countries. New Haven: Yale University Press.

[54] Linz J \& Stepan A .(1996).Toward Consolidated Democracies Journal of Democracy 7.(2): , 1433

[55] Mayah, E. (2016).Special report: Inside Agatu killing field: blood on the streets, charred bodies everywhere. Premium Times

[56] Mustapha,A.(2004). Ethnic Structure, Inequality and Governance of the Public Sector in Nigeria. United Nations Research for Social Development (UNRISD).

[57] Nicolson, I. (1966). "The Machinery of the Federal and Regional Government" In Mackintosh, J.P (ed) Nigerian Government and Politics. London: Allen and Unwin.

[58] Nnoli.O.(1978). Ethnic Politics in Nigeria. Enugu: Fourth Dimension Publishers. 
[59] Nwankpa, M. (2014). The Politics of Amnesty in Nigeria: A Comparative Analysis of the Boko Haram and Niger Delta Insurgencies. Journal of Terrorism Research. 5, (1) 67-77

[60] Obi, C. (2001).The Changing Forms Of Identity Politics in Nigeria Under Economic Adjustment. The Case of the Oil Minorities Movement of the Niger Delta. Research $\quad$ Report $\quad$ No. 119 NordiskaAfrikainstitutet, Uppsala.

[61] O'Connel, J. (1971).Authority and Community in Nigeria "In R Melson and H Wolpe (eds), Modernization and The Politics of Communalism (East Lansing: Mitchigan State University Press.

[62] Ojiako, J. (1981).Nigeria; Yesterday, Today, and...? Onitsha: Africana Educational publishers (Nig.)Ltd.

[63] Omale, D.(2013). Terrorism and Counter Terrorism in Nigeria: Theoretical Paradigms and Lessons for Public Policy. Canadian Social Science, 9 (3), 96-103.

[64] Premium Times,(2016). "Nigerian Army, Shiites in war of words after deadly Zaria attack that killed many". Premium Times Newspaper.

[65] Osaghae, E.(1986). "Do Ethnic Minorities Still exist in Nigria?',Journal of Commonwealth and Comparative Politics. 24 (2):151-167.

[66] Osaghae, E. (1991).Ethnic Minorities and Federalism in Nigeria" African Affairs. African Political Economy. 90, (359):237-258.

[67] Otite, .(1990). Ethnic Pluralism and Ethnicity in Nigeria.Ibadan: Shaneson C.I. Ltd.

[68] Posner D \& Young D.(2007). The Institutionalization of Political Power in Africa Journal of Democracy 18,(3), 127-140.

[69] Rotchild,D.(1963). Safeguarding Nigeria's Minorities"Duquesne Review.

[70] Suberu, R.(1996). Ethnic Minority Conflicts in Nigeria and Governance Ibadan:Spectrum Books Limited, Ibadan and French Institute for Research in Africa(IFRA)Ibadan,Nigeria.

[71] Scott W. (2004). Institutional Theory: Contributing to a Theoretical Research Program. In Ken G. Smith \& Michael A. Hitt, eds. Great Minds in Management: The Process of Theory Development, Oxford UK: Oxford University Press.

[72] Tamuno, T. (1970). Separatist Agitation in Nigeria since 1914, Journal of Modern African Studies, 8 (4). 563-84

[73] UN. (1994). Declaration on Measures to Eliminate International Terrorism. United Nations Audiovisual Library of International Law pp1-6 Available www.un.org/law/avl.

[74] UNDP. (2006).Niger Delta Human Development Report. Lagos, Nigeria

[75] UNEP (2011). Environmental Assessment of Ogoniland. Nairobi, Kenya

[76] Wallestein. I. (1963). "Ethnicity and National Integration in West Africa",In H.Eckstein \& David Apter, Comparative Politics: A Reader. New York:Free Press of Glencoe

[77] Willinks ,H .(1958).Nigeria; Report of the Commission Appointed to Enquire into Fears of Minorities and the Means of Allaying Them, London ,Her Majesty's Stationery Office.

[78] Winsor, M. (2015)."Number of Nigerians Displaced by Boko Haram Increases To 2.1 Million, International Organization For Migration Says "Available at http://www.ibtimes.com /numbernigerians-displaced-boko-haram-increases-21 million international organization-20837 97 